\title{
IPO Grading: Is There Any Value Addition?
}

\author{
Narender Miryala \\ Research Scholar, Department of Business Management, Osmania University, Hyderabad- Telangana State
}

\begin{abstract}
Two most imperative reforms the Indian IPO market has seen are Grading of IPOs by Credit Rating Agencies (CRAs) and introduction of issues through Book Building Process for efficient price discovery. SEBI is the only Capital Market Regulator in the world which made IPO Grading mandatory with effect from May 1, 2007 followed by which all the issuances were graded on the scale of 1 to 5 in which 1 indicates Poor Fundamentals and 5 indicate Strong Fundamentals. IPO Grading would help investors especially Retail Individual Investors (RIIs) who will not be able to take informed decisions by assessing IPOs objectively as the Information Asymmetry and Behavioral biases prevalent in the markets. In the light of SEBI scuffled the idea of mandatory IPO Grading and made it voluntary, this paper attempts to find the short- run and long-run performance of different grade IPOs to see whether higher grading has any impact on generating improved returns to the investors by analyzing the data using One Factor ANOVA. The analysis is made on the issues, which were issued under Book Building and listed on National Stock Exchange during January 1, 2008 to June 2013.
\end{abstract}

Keywords: SEBI, IPO Grading, Book Building

JEL Classification: G11; G12.

\section{Introduction}

Indian Economy is opened up and structural reforms were initiated in the year 1991. Deregulation of financial sector has given burgeoning growth to Initial Public Offering (IPO) markets. Indian Financial Markets had perceived important mechanisms to bring in the best practices, which makes the Indian markets to be on par with the developed markets. The two historical reforms in the Indian IPO markets are introduction of IPO grading and issue through book building process. This would not have been a reality in India if Securities and Exchange Board of India (SEBI) is not set up under the SEBI Act, 1992. With its strong commitment to meet the set objectives, SEBI initiated so many reforms.

SEBI is the only capital market regulator in the world which has made IPO grading mandatory with effect from May 1, 2007, with the expectation that the external certification from Credit Rating Agencies (CRAs) would minimize the information asymmetry prevalent in the markets. The participation from domestic retail and institutional investors is been increasing in the equity markets. Investment decisions are always come with lot of complexity, as they require analysis of lot of critical documents about the company, industry to which the company belongs to and macro-economic factors. The grading has to compress all the important information into an ,easy-to-use ${ }^{\text {ee }}$ symbol. The grading is to help retail investors in taking objecting judgment especially issues from small and unknown firms.

However, not to much surprise SEBI scrapped the idea of mandatory IPO grading and made it voluntary. There are many supporters who welcomed this move as (i) the ratings may evaluate the company, but they do not comment on the pricing, so the investors were never sure about pricing, which is a key part in the investment decision (ii) grading a product, as equity is always a difficult issue as the prices keep on fluctuates. In this paper attempt is to find the shortrun and long- run performance of different grade IPOs to see whether higher grading has any impact on generating improved returns to the investors by analyzing the data using One Factor ANOVA.
This paper is organized as follows. Section II explains the characteristics of Book Building Process and IPO grading; Section III reviews existing literature; Section IV defines research objectives and hypothesis; Section V describes the sources of data and research methodology; Section VI exemplifies the results and explanations; and Section VII determines the findings, conclusions and implications for further research.

\section{Characteristics of Book Building Mechanism and IPO Grading}

\subsection{Characteristics of Book Building Mechanism}

Issues made by an Indian company can be classified as Public, Rights, Bonus and Private Placement. Public issue is the offer of securities to new investors for becoming part of the shareholders ${ }^{e}$ family of the issuer. The public issue can be done by either Initial Public Offering (IPO) or Further Public Offering (FPO). IPO is the fresh issue of securities or offer of existing securities for sale or both for the first time to the public by an unlisted company. The most important component of the entire IPO is arriving at the price. Fixation of pricing has undergone lot of changes and finally issue of shares through book building mechanism has much importance because of recommendations of The Malegam Committee Report in 1995. SEBI brought forward the guidelines of issue of shares through book building mechanism in 1998. SEBI defines "book building as a process undertaken by which demand for the securities proposed to be issued by a body corporate is elicited and built up and the price for such securities is assessed for the determination of the quantum of securities to be issued by means of a notice, circular, advertisement, document of information memoranda or offer document".

Book building is the process of price discovery. The issuer in consultation with Book Running Lead Manager (BRLM) discloses price band. The price band is a band of price with in which investors can bid. The spread between the floor and the cap of the price band shall not be more than $20 \%$. The 


\section{International Journal of Science and Research (IJSR) \\ ISSN (Online): 2319-7064 \\ Index Copernicus Value (2013): 6.14 | Impact Factor (2014): 5.611}

price band can be revised. If revised, the bidding period shall be extended for a further period of three days, subject to the total bidding period not exceeding thirteen days. The price band should be disclosed at least two working days prior to the opening of the issue. Once the bidding process is complete, based on the demand for securities a final ,cut-offe price is arrived. The basis of allotment is then finalized based on the cut-off price and allotment/refund is undertaken. Only the retail individual investors i.e. investors who are applying for securities worth up to Rs 2,00,000 have the option of ticking the cut-off option. It indicates their willingness to subscribe to shares at any price discovered within the price band by which they will overcome the problem of non-allotment of shares, as there is a chance of quoting a price, which is lesser than the cut-off price.

\subsection{Characteristics of IPO Grading}

IPO grading has been introduced as an endeavor to make additional information available for the investors in order to facilitate assessment of equity issues in a more objective manner. The grade, which is assigned on a five-point scale with a higher score indicating stronger fundamentals and vice versa represents a relative assessment of the fundamentals of the issue in relation to the other listed equity securities in India. IPO grade 1, 2, 3, 4 and 5 represents poor, below average, average, above average and strong fundamentals respectively. IPO grading is assigned by CRAs that are registered with SEBI for all IPOs of equity shares or any other security that may be converted into or exchanged with equity shares later. The firm engrossed in raising capital through IPO has to bear the expenses and the issuer cannot reject the grade assigned by CRA irrespective of whether the grade is acceptable or not to the issuer. The prospectus must contain grade/s given to the issue by all CRAs approached by the issuer. IPO grading in no way delay the issue process as issuance of observation by SEBI and the grading process, performed independently. IPO grading is an ,easy-to-use ${ }^{\text {ee }}$ symbol, which is obtained by proper analysis of the business prospects and competitive position comprising of industry and company prospects, financial position, management quality, corporate governance practices, compliance and litigation history and risks and prospects of new projects. SEBI as a market watch dog do not play any role in the assessment made by CRA, observations on the IPO document are entirely independent of the IPO grading process and do not pass any judgment on the quality of the issuer company based on grading. An IPO grade is not a suggestion or recommendation as to whether one should subscribe to the IPO or not. The most important factor an IPO grading fails to take into is the share price. Since IPO grading does not consider the issue price, the investor needs to make an independent judgment regarding the price at which to subscribe to the shares.

\section{Review of Literature}

Though there is enormous amount of literature available on IPO pricing, the extent of literature pertaining to grading of IPOs is very limited.

Winner's Curse Hypothesis: Rockes (1986) asymmetric information theory (also called winner curse hypothesis) is most high-ranking model that has been developed to explain the new issue anomaly. Rockes model is based on two key assumptions: two kinds of investors, those who are informed about the true value of the firm and those who are completely uninformed about the true value of the firm. Informed investors are having knowledge about the future prospects and will only attempt to buy when the issue is under-priced .Uninformed investors on the other hand, don't know about under-pricing and over pricing of issues, and therefore don't discriminate between issues. They suffer from a winner curse as uninformed investors earn negative initial return. They get all the shares they want of the poor issues and they get small fraction of good issues. Due to this adverse selection problem, the uninformed investors will exit the market unless IPOs are sufficiently under-priced on average to compensate them for their informational handicap.

Information Gathering Theory: Benvenistc and Spindt (1989) introduced the "Information gathering theory" and stated that underpricing is a means to induce informed investors to reveal private information about the demand for shares in the pre-selling phase. In the IPO market, lead managers consult clients before setting offer price in prospectus. Lead managers may deliberately underprice an IPO, to attract more and more clients. They gather demand information from their clients during the pre-selling period, which forms the basis for pricing the issue. So the merchant bankers play game with many of their large clients.

Signal Theory: Allen and Faulhaber (1989) said that underpriced new issues "Leave good taste in investors"e mouths". Firms tend to signal their quality to investors by offering their shares at relatively lower values and subsequent adjusting for the loss in their seasoned offering.

Kam C. Chan and Yung Ling Lo in their article credit ratings and long-term IPO performance found that provision of credit ratings prior to IPO reduces information asymmetry and improves market efficiency. There is reduction in information risk and price discounts by the increase in disclosure through credit ratings. IPOs that have credit ratings are less underpriced and more positively perceived by outside investors than the IPOs not having credit rating. The market reactions for rated IPOs are immediate and more complete while the long-term performance is insignificant because of reduction in the information asymmetry.

The findings of Heng (Hunter) An, and KamC.Chan in Credit ratings and IPO pricing of the analysis of U.S. common share IPOs from 1986- 2004, suggests that rated IPOs underpriced significantly less than the unrated IPOs. Credit rating levels do not have a significant effect on IPO under pricing. IPO firms with high credit ratings are not necessarily underpriced less than those with low ratings. Credit ratings reduce the degree of price revision during the book building process. Credit ratings also reduce the aftermarket volatility in the post- IPO period.

Mandatory IPO grading: Does it help pricing efficiency? By Joshy Jacob and Sobesh Kumar Agarwalla finds that both the institutional and retail demand for IPOs is 


\section{International Journal of Science and Research (IJSR) \\ ISSN (Online): 2319-7064 \\ Index Copernicus Value (2013): 6.14 | Impact Factor (2014): 5.611}

apparently influenced by the grades. The demand from QIBs is weaker for the relatively low grade IPOs, compared to the high grade or ungraded IPOs. The demand from retail investors for both low and high grade IPOs appears to be negative relative to the ungraded IPOs. The weaker demand for the low grade IPOs, compared to the ungraded IPOs, tentatively suggests a guidance role for the IPO grade in the case of the retail investors.

Information content of IPO grading by Deb. S. S. and Marisetty V. B (2010) found that IPO grade influences both the retail as well as institutional investor's subscription levels.

Grading, transparent books and initial public offerings by Khurshed et al. (2011) establish that IPO grading is not significant in the retail demand. It is found that QIBs demand is weaker for low-grade issues.

\section{Research Objectives and Hypotheses}

The paper attempts to find is there any significant variance in the returns generated by different grading IPOs in the short- run and long run. It is also aimed to know is it the grading, which makes the Retail Individual Investors (RIIs) subscription to the IPO or because of the other factors like issue size and number of times the issue, is subscribed by Qualified Institutional Buyers (QIBs).

1) To know the variance in the returns generated by different grading IPOs in the short-run.

2) To know the variance in the returns generated by different grading IPOs in the long run $(3,6,9$, and 12months).

$\mathrm{H}_{11}$ : There is significant variance in the returns generated by different grading IPOs in the short-run.

$\mathrm{H}_{12}$ : There is significant variance in the returns generated by different grading IPOs in the 3 - month period.

$\mathrm{H}_{13}$ : There is significant variance in the returns generated by different grading IPOs in the 6- month period.

$\mathrm{H}_{14}$ : There is significant variance in the returns generated by different grading IPOs in the 9-month period.

$\mathrm{H}_{15}$ : There is significant variance in the returns generated by different grading IPOs in the 12-month period.

\section{Sources of Data and Research Methodology:}

\subsection{Sample and Data Collection Methods}

The sample in this study comprises all the new equity issues offered through book building mechanism on the National Stock Exchange (NSE), one of the major stock exchanges in India. The sample is taken for the period January 1, 2008 to June 5, 2013. The reason for selecting this period is the IPO grading is made mandatory in Indian markets from May 1, 2007. After excluding the offer for sale issues, and follow on public offers, sample is left with 135 IPOs for short-run analysis and the sample size changes for long-run based on the period under consideration.

For short-run analysis, the data is collected for closing prices of the issue on the listing day, closing value of the Nifty on the listing day, issue price and closing value of the Nifty on the date of issue from NSE website. Then, for long-run analysis the monthly adjusted closing prices (adjusted for bonus issues, stock splits and dividend payments) of the issues and closing values of the Nifty were collected from Capitaline database.

\subsection{Calculation procedure for short-run and long run}

In the short-run the returns generated by different grading IPOs are calculated in consistent with the existing literature. In order to know market adjusted returns the market returns subtracted from simple returns generated by the issue.

$$
\mathbf{R}_{\mathrm{it}}=\left(\frac{\text { Pit }- \text { Pio }}{\text { Pio }^{*}}\right)^{* 100} \text { (Equation 1) }
$$

Where

$\mathrm{P}_{\mathrm{it}}$ is the closing price of the issue, $\mathrm{i}^{\mathrm{ee}}$ at time, $\mathrm{t}^{\mathrm{ee}}$

$\mathrm{P}_{\text {io }}$ is the offer price of the issue.

If $\mathrm{R}_{\mathrm{it}}$ is positive one can infer that the investor gained on this issue, if $\mathrm{R}_{\mathrm{it}}$ is negative investor has lost and if $\mathrm{R}_{\mathrm{it}}$ is zero investor has gained nothing on this issue.

Because of the lag between the offer closing and listing of the issue the issue price may change from the day of offer closing to listing because of overall market movements. In order to calculate returns adjusted for market movements the returns from the market have to be calculated first.

$$
\mathrm{N}_{\mathrm{it}}=\left(\frac{V t-V o}{V 0}\right) * 100
$$

Where $\mathrm{V}_{\mathrm{t}}$ is the closing value of Nifty on day, $\mathrm{t}^{\text {ee }}$

$\mathrm{V}_{\mathrm{o}}$ is the closing value of Nifty on the day of offer closing. Positive $\mathrm{N}_{\mathrm{it}}$ indicates the market has moved up; negative $\mathrm{N}_{\mathrm{it}}$ indicates market has weakened and if it is zero we can infer that market remained unchanged in the gap between offer closing and listing.

Market adjusted returns of the issue is calculated by subtracting $\mathrm{N}_{\mathrm{it}}$ from $\mathrm{R}_{\mathrm{it}}$.

$$
A R_{i}=\left(R_{i t}-N_{i t}\right)
$$

The positive value of Actual returns (adjusting for market movements) specifies that the issue is under-priced; negative value specifies that the issue is over-priced and zero indicates the issue is fairly priced.

To bring in similarity among the issues (as there will be a variance in the time lag between numbers of days of offer closing to offer listing in the secondary market), the actual returns of the issue is annualized by using the following formula.

\section{Annualized $A R_{i}=A R_{i}^{*}(360 / N)$}

Where, $\mathrm{N}$ is the number of days between offer closing and listing and listing of the issue. 


\section{International Journal of Science and Research (IJSR) \\ ISSN (Online): 2319-7064 \\ Index Copernicus Value (2013): 6.14 | Impact Factor (2014): 5.611}

Then, the annualized $A_{\mathrm{i}}$ for the issues is separated according to their grading and the impact of grading on the returns generated was analyzed using one factor Analysis of Variance (ANOVA).

The ANOVA is designed to test whether a significant variance exists among the three or more sample means. In this analysis, the variance in a set of data is divided into variation within-samples or groups, and variation betweengroups or between samples or between columns.

For the long run analysis, the returns are calculated at monthly intervals for 3, 6, 9 and 12 months from listing. The long run performance is reviewed using Buy and Hold Abnormal Returns (BHAR). For each time period, the returns were segregated according to their grading and ANOVA is performed to know is there any significant variance in the returns generated by different grading IPOs in the respective intervals.

$$
B H A R_{i, t}=\left[\prod_{t=1}^{T}\left(1+R_{i, t}\right)-1\right]-\left[\prod_{t=1}^{T}\left(1+R_{m, t}\right)-1\right]
$$

Where

$\mathrm{BHAR}_{\mathrm{i}, \mathrm{t}}=$ Buy and Hold Abnormal Returns for stock i for the month under consideration.

$\mathrm{R}_{\mathrm{i}, \mathrm{t}}=$ Monthly return on the stock i for the $\mathrm{t}$ month.

$\mathrm{R}_{\mathrm{m}, \mathrm{t}}=$ Monthly return on the market for the $\mathrm{t}$ month.

\section{Results and Explanations}

Table 2: Year wise and grade wise classification of number

\begin{tabular}{|c|c|c|c|c|c|c|c|}
\hline $\begin{array}{c}\text { Year/ } \\
\text { Grade }\end{array}$ & 2008 & 2009 & 2010 & 2011 & 2012 & $2013^{*}$ & $\begin{array}{c}\text { Total No. } \\
\text { of issues }\end{array}$ \\
\hline Grade 1 & 2 & 2 & 1 & 3 & 1 & 0 & 9 \\
\hline Grade 2 & 7 & 3 & 18 & 10 & 0 & 0 & 38 \\
\hline Grade 3 & 14 & 8 & 19 & 10 & 3 & 2 & 56 \\
\hline Grade 4 & 4 & 2 & 15 & 2 & 4 & 0 & 27 \\
\hline Grade 5 & 0 & 0 & 2 & 1 & 1 & 1 & 5 \\
\hline & 27 & 15 & 55 & 26 & 9 & 3 & $\mathbf{1 3 5}$ \\
\hline
\end{tabular}

Table 3: Year wise and grade wise classification of issue size and average issue size (RsCrore)

\begin{tabular}{|c|c|c|c|c|c|c|c|c|}
\hline Year/Grade & 2008 & 2009 & 2010 & 2011 & 2012 & 2013 & Total Issue Size & Average Issue Size \\
\hline Grade 1 & 225.88 & 72.01 & 63.75 & 115.98 & 55.00 & 0.00 & 532.62 & 59.18 \\
\hline Grade 2 & 528.99 & 221.08 & 3539.34 & 738.67 & 0.00 & 0.00 & 5028.08 & 132.32 \\
\hline Grade 3 & 3432.40 & 11669.62 & 6645.15 & 2293.11 & 992.79 & 364.81 & 25397.88 & 453.53 \\
\hline Grade 4 & 13263.78 & 3055.21 & 11037.72 & 1128.25 & 4494.09 & 0.00 & 32979.05 & 1221.45 \\
\hline Grade 5 & 0.00 & 0.00 & 16436.95 & 1245.00 & 663.31 & 927.37 & 19272.63 & 3854.53 \\
\hline & 17451.05 & 15017.92 & 37722.91 & 5521.01 & 6205.19 & 1292.17 & 83210.25 & 616.37 \\
\hline
\end{tabular}

*: Year 2013 is considered up to June.

From the table 2 and 3, we can accomplish that more number of issues are in the grade 3 followed by grade 2 , grade 4, grade 1 and grade 5 . Year 2010 has seen more number of issues from all the graded issues except grade 1 . Total issue size is very high for grade 4 followed by grade 3 , 5,2 and 1 . Even though there are only five issues in grade 5 the issue size is almost four times to the grade 2 issues with a number of issues of 38. By comparing the average issue size, we can say that higher the grade, larger is the issue size. The average issue size of grade 5 is galloping Rs 3, $845.53 \mathrm{cr}$ whereas for the grade 1 it is minimal with Rs $59.18 \mathrm{cr}$.
Table 4: Grade wise classification of under- priced and over- priced issues in the short- run

\begin{tabular}{|c|c|c|}
\hline Grade & $\begin{array}{c}\text { No. of Under } \\
\text { Priced Issues }\end{array}$ & $\begin{array}{c}\text { No. of Over } \\
\text { Priced Issues }\end{array}$ \\
\hline Grade 1 & 6 & 3 \\
\hline Grade 2 & 20 & 18 \\
\hline Grade 3 & 25 & 31 \\
\hline Grade 4 & 19 & 8 \\
\hline Grade 5 & 5 & 0 \\
\hline
\end{tabular}




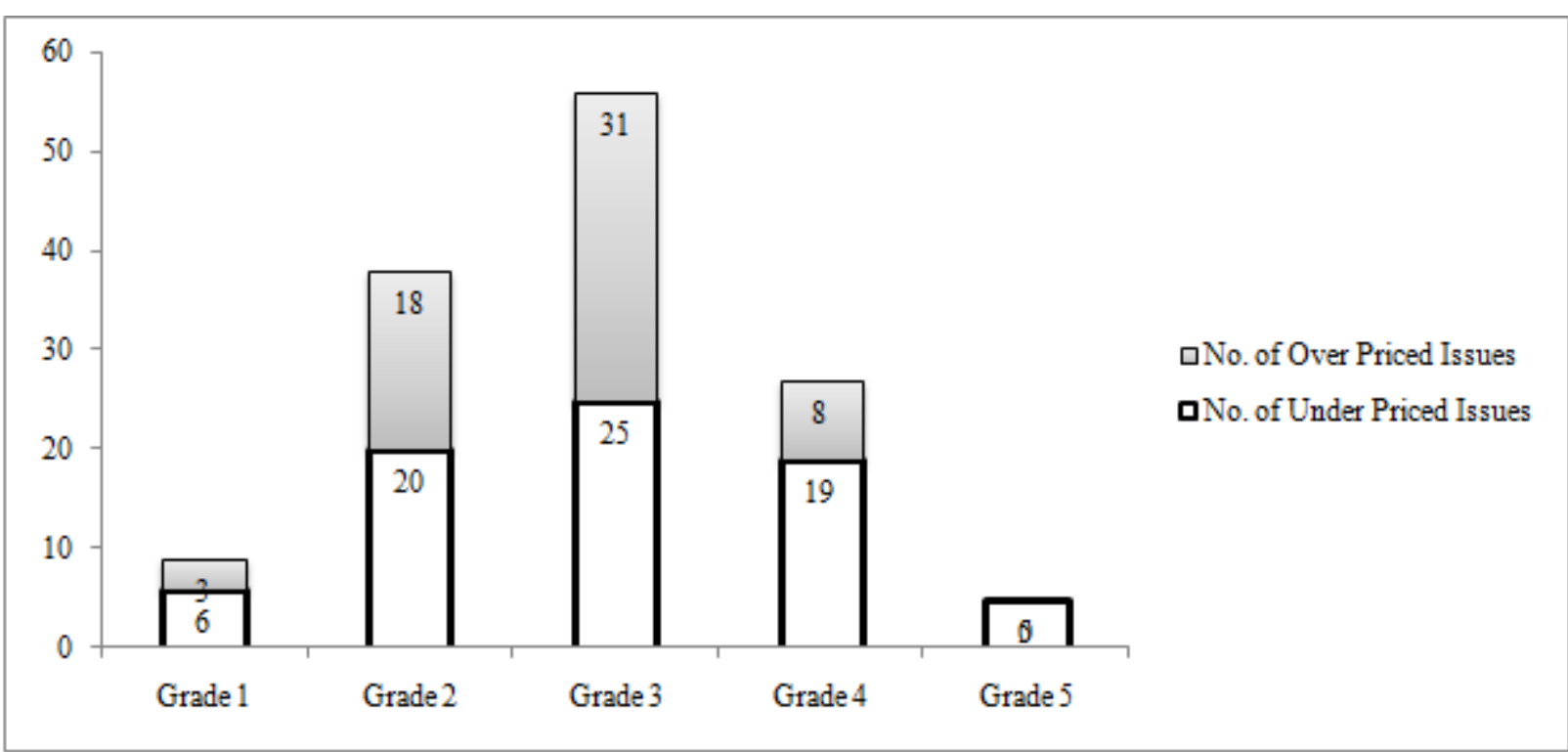

Figure 1: Classification of issues into underpriced and overpriced issues

\section{Findings, conclusions and implications for further research}

\subsection{Findings}

Table 5: Result of ANOVA on the basis of F- test and Pvalues

\begin{tabular}{|c|c|c|c|c|c|}
\hline Type & $\begin{array}{c}\text { Null } \\
\text { Hypothesis }\end{array}$ & $F$ & F Critical & P-value & Result \\
\hline Short-run & H01 & 1.471262 & 2.4414 & $\mathbf{0 . 2 1 4 6}$ & $\begin{array}{c}\text { Failure to } \\
\text { Reject NH }\end{array}$ \\
\hline 3-month & H02 & 1.66734 & 2.4506 & $\mathbf{0 . 1 6 2 3}$ & $\begin{array}{c}\text { Failure to } \\
\text { Reject NH }\end{array}$ \\
\hline 6-month & H03 & 2.7656 & 2.451 & $\mathbf{0 . 0 3 0 8}^{*}$ & Reject NH \\
\hline 9-month & H04 & 3.868 & 2.451273 & $\mathbf{0 . 0 0 5 5}^{*}$ & Reject NH \\
\hline 12-month & H05 & 4.9304 & 2.453 & $\mathbf{0 . 0 0 1 0}^{*}$ & Reject NH \\
\hline
\end{tabular}

In the short- run (between offer closing and listing), there is no significant variance in the returns generated by different grading IPOs.

In the long- run (3 months between offer closing and listing), there is no significant variance in the returns generated by different grading IPOs.

In the long- run (6 months between offer closing and listing), there is significant variance in the returns generated by different grading IPOs.

In the long- run (9 months between offer closing and listing), there is significant variance in the returns generated by different grading IPOs.

In the long- run (12 months between offer closing and listing), there is significant variance in the returns generated by different grading IPOs.

\subsection{Conclusions}

Grading of IPOs by CRAs is not showing any importance in the returns generated by different graded IPOs for short- run and for a period of 3- months under consideration. However,
IPO grading is showing significant variance in the returns generated for longer horizons.

\subsection{Implications for Further Research}

The present study examines the variance in the returns generated by different grading IPOs in the short- run and long- run; and influence of certain explanatory variables on the levels of RIIs subscription. The study is confined only to initial public offerings that are issued through book building mechanism on National Stock Exchange in India. Further studies can examine the significant variance in the returns generated by different grading IPOs in other major exchanges and by considering fixed price issues.

\section{References}

[1] An, H. H. and Chan, K. C. (2008).Credit ratings and IPO pricing. Journal of Corporate Finance, 14(5):584595.

[2] Benveniste, L and P. Spindt,(1989), 'How Investment Bankers Determine the Offer Price and Allocation ofNew Issues', Journal of Financial Economics, Vol. 24:343- 361.

[3] Deb, S. S. and Marisetty, V. B. (2010).Information content of IPO grading. Journal of Banking \& Finance, 34(9):2294- 2305.

[4] Frequently asked questions on IPO grading, retrieved from www.sebi.gov.in/faq/ipograding.pdf.

[5] Joshy Jacob, Sobesh Kumar, (2012), „Mandatory IPO grading: Does it help pricing efficiency? Online paper, http://papers.ssrn.com/sol3/papers.cfm?abstract_id=219 5037.

[6] Kam C. Chan and Yung Ling Lo, (2011), Credit ratings and long-term IPO performance, Journal of Financial Economics, Vol. 35:473- 483.

[7] Khurshed, A., Paleari, S., Pande, A., and Vismara, S. (2011). Grading, transparent books and initial public offerings.Online http://www.unibg.it/dati/persone/1823/4211Grading\%20paper.pdf. 


\section{International Journal of Science and Research (IJSR) \\ ISSN (Online): 2319-7064}

Index Copernicus Value (2013): 6.14 | Impact Factor (2014): 5.611

[8] Krishnawamy and Obul Reddy: "Research Methodology and Statistical Analysis", (2012), Himalyaya Publishing House, Third Edition, page 452456.

[9] Rock, K. (1986). Why new issues are underpriced. Journal of financial economics, 15(1):187- 212.

[10] S SS Kumar (2008), Short and long- run performance of Book built IPOs in India. Online paper, http://dspace.iimk.ac.in/bitstream/2259/523/1/sssk.pdf 